\title{
Unraveling genetic factors involved in intelligence, educational attainment and socioeconomic standing: what are the implications for childhood mental health care professionals?
}

\author{
Maria Melchior ${ }^{1}$ - Johannes Hebebrand ${ }^{2}$
}

Published online: 8 March 2018

๑) Springer-Verlag GmbH Germany, part of Springer Nature 2018

Examinations of children and adolescents presenting to child mental health services often include a clinical assessment of intelligence. To obtain information beyond an experienced clinician's estimate, IQ tests are routinely used. This information is valuable to assess coping strategies and school competency of an individual patient. The assessment of cognitive functioning is also of fundamental importance because many outcomes are directly or indirectly related to cognition. The fact that a PubMed search (look-up February 4,2018) of articles published in European Child and Adolescent Psychiatry (ECAP) since 2017 revealed a total of ten articles [1-10] for "intelligence" and 30 for "cognit*" (approximately one-eighth of all ECAP articles published 2017 or 2018) underscores this relevance.

Before we dwell on the detection of genetic variants associated with intelligence, we provide a brief overview of the measurement of intelligence itself, a topic of great controversy. One measure, routinely used by clinicians and researchers nowadays, is based on ideas conveyed by Charles Spearman, a psychologist and statistician, who hypothesized that because human cognitive abilities tend to correlate, they reflect a unique construct-the " $\mathrm{g}$ factor" (general intelligence). In 1905, Binet and Simon [11] proposed the first standardized test measuring children's cognitive abilities (the Binet-Simon test), modified by William Stern in 1912

Maria Melchior

maria.melchior@inserm.fr

$\triangle$ Johannes Hebebrand

johannes.hebebrand@uni-due.de

1 Department of Social Epidemiology, INSERM, Sorbonne Université, Institut Pierre Louis d'Epidémiologie et de Santé Publique IPLESP, 75012 Paris, France

2 Department of Child and Adolescent Psychiatry, Psychosomatics and Psychotherapy, University Hospital Essen, University of Duisburg-Essen, Wickenburgstr. 21, 45147 Essen, Germany to create an 'intelligence quotient' (IQ) relative to the child's age, and expanded by David Wechsler in 1939 to be applicable to adults [12]. In general, tests of IQ involve verbal and non-verbal exercises examined in terms of success and speed of execution. The discussion regarding the different types of IQ tests and their respective advantages/disadvantages is beyond the scope of this article. However, it is important to note that the way in which intelligence is measured is, by design, predictive of abilities that are correlated with individuals' school achievement, later job performance, as well as socioeconomic position [13]. Some of the main criticisms of standard IQ tests are that: (a) they consider intelligence to be fixed; (b) they are not appropriate for children with disabilities; (c) they may be culturally biased; and (d) they fail to capture important life abilities such as creativity, critical thinking or sense of humor.

The contribution of innate characteristics is often assessed with estimates of "heritability", defined as the proportion of the variance of a particular trait attributable to genetic factors within a given population. The search for hereditary traits that predict intelligence within the normal range is longstanding, and goes back to at least the nineteenth century and research conducted by Galton [14]. Heritability is generally estimated in twin samples, where monozygotic and dizygotic twins are compared to draw inferences regarding the role of shared, non-shared environmental and heritable factors to a given trait. With regard to IQ, estimates of heritability range between 0.4 in early childhood to 0.85 in adulthood [15]. Breaking general adult cognitive ability into specific sub-domains, heritability estimates tend to be higher for spatial ability and perceptual speed (above 0.6) than for verbal ability and memory (below 0.5 ).Because intelligence is correlated with educational achievement and socioeconomic characteristics, it is worthwhile to consider heritability estimates for these phenotypes as well. Thus, for educational achievement, measured as success on standard tests in primary or secondary school, heritability estimates 
are also generally above 0.6 , while $0.4-0.6$ of the variation in socio-economic characteristics, such as living in a deprived neighborhood, has been estimated to be heritable [16, 17].

Recently, for the first time, research has proved successful in identifying polygenic loci involved in intelligence [18-20], educational attainment $[18,21,22]$, as well as social deprivation and household income [23]. These investigations based on very large samples and meta-analyses thereof identified up to 187 loci involved in intelligence [20]. Whereas each locus has a small effect, the total IQ variance explained by all of the 187 loci amounted to approximately $4-7 \%$ in three different study groups. This is roughly double the currently explained variance for the phenotype body mass index (BMI; $\mathrm{kg} / \mathrm{m}^{2}$ ), for which over 200 genome-wide significant loci have been detected [24]. For educational attainment, defined via the number of attended school years, the estimated effect sizes of the lead single nucleotide polymorphisms (SNPs) ranged from 0.014 to 0.048 standard deviations per allele equivalent to $2.7-9.0$ weeks of schooling [21].

SNP-based heritability estimates make use of all SNP data for a particular phenotype, not just those few SNPs that surpassed the genome-wide significance threshold of $p \leq 5 \times 10^{-8}$ in a respective genome-wide association studies (GWAS). Such SNP-based heritability estimates 'explain' up to $25 \%$ of the variance in IQ [18-20], thus-and similar to other complex phenotypes-remaining well below the heritability estimates based on twin or family studies, which typically range from 0.5 to 0.8 . Similarly, SNP-based heritability estimates explain 0.11 and 0.21 of variation in, respectively, household income and social deprivation [23]. This phenomenon of mismatch between twin (or family) study-based heritability estimates and SNP-based heritability estimates, referred to as the "missing" [25] or "hidden" [26] heritability, has been observed for most traits and is the object of many scientific debates (see, e.g. [27]).

The elucidation of genes with small effect sizes for the dimensional phenotype 'IQ' complements longer standing research into the molecular mechanisms underlying intellectual disability. The search for variants with small effect sizes based on GWAS has just begun; a much improved insight will evolve over the upcoming years as sample sizes increase, techniques of investigation become increasingly sophisticated and bio-statistical methodology improves. As with other polygenic traits, the path from (a) identification of a locus via genome-wide significant SNPs to (b) the underlying gene and (c) the elucidation of the functional implications of genetic variation is arduous. Currently, pathway analysis has implicated genes involved in neurogenesis and myelination in addition to genes expressed in synapses [20]. Furthermore, "general cognitive ability" (i.e., "g"), usually studied as a proxy of intelligence, is a complex phenotype with many different sub-domains. As such, studies need to disentangle the genetic architecture of these sub-domains. For a start, Davies et al. [18] determined that SNP-based heritability was highest for verbal-numerical reasoning (0.31) followed by that for reaction time (0.11); for memory, the SNP-based heritability estimate was lowest (0.05).

The insight into the genetic architecture of the traits 'intelligence' and 'educational attainment' has additionally allowed the calculation of SNP-based genetic correlations between these phenotypes and with other phenotypes such as mental disorders. The genetic correlation between educational attainment and intelligence has been estimated to be $r_{\mathrm{g}}=0.7$ [19], indicating a high overlap in the polygenic basis of the two phenotypes at the DNA level. Genetic correlations between social deprivation and years of education and childhood IQ are estimated to be, respectively, about 0.5 . Higher genetic correlations of 0.9 and 0.7 were observed for household income and years of education and childhood IQ, respectively [23]. As for mental disorders/ traits, positive genetic correlations between educational attainment and anorexia nervosa, bipolar illness and schizophrenia, respectively, have been detected. The respective correlations between educational attainment, neuroticism and Alzheimer's disease have been found to be negative [21, 28]. Genetic correlations with educational attainment and intelligence have also been identified for somatic and anthropometric traits (see Table 1). Positive genetic correlations can imply that a proportion of the genetic variants are directly involved in both phenotypes (biological pleiotropy; see [24]); in negatively correlated phenotypes, the two phenotypes also share a proportion of predisposing loci albeit with a preponderance of opposite alleles. In contrast to biological pleiotropy, mediated pleiotropy [23] entails that the correlation is not causal but instead due to a third phenotype/ condition that underlies the observed genetic correlation.

These studies mark the entry into the molecular dissection of complex dimensional phenotypes such as intelligence. The novel findings have face value. Innate, biological characteristics can influence cognitive abilities, which predict educational achievement, which in turn is the basis of socioeconomic position in modern Western societies. In other words, intelligence and socioeconomic standing reflect what philosopher Jean-Jacques Rousseau referred to as a 'natural inequality' [29]. But, is it really that simple?

It is important to bear in mind that twin- and family-based heritability estimates for cognitive abilities of normal range are typically quite high, but nevertheless vary [30]. This heterogeneity may be due to methodological differences in genetic and statistical tests used, in sample sizes, or in the way in which individuals' cognitive abilities are ascertained. In particular, it is well known that tests measuring cognitive ability only measure certain types of intelligence and are subject to a 'practicing effects' [31]. Therefore, results of studies using general, standardized measures of intelligence 


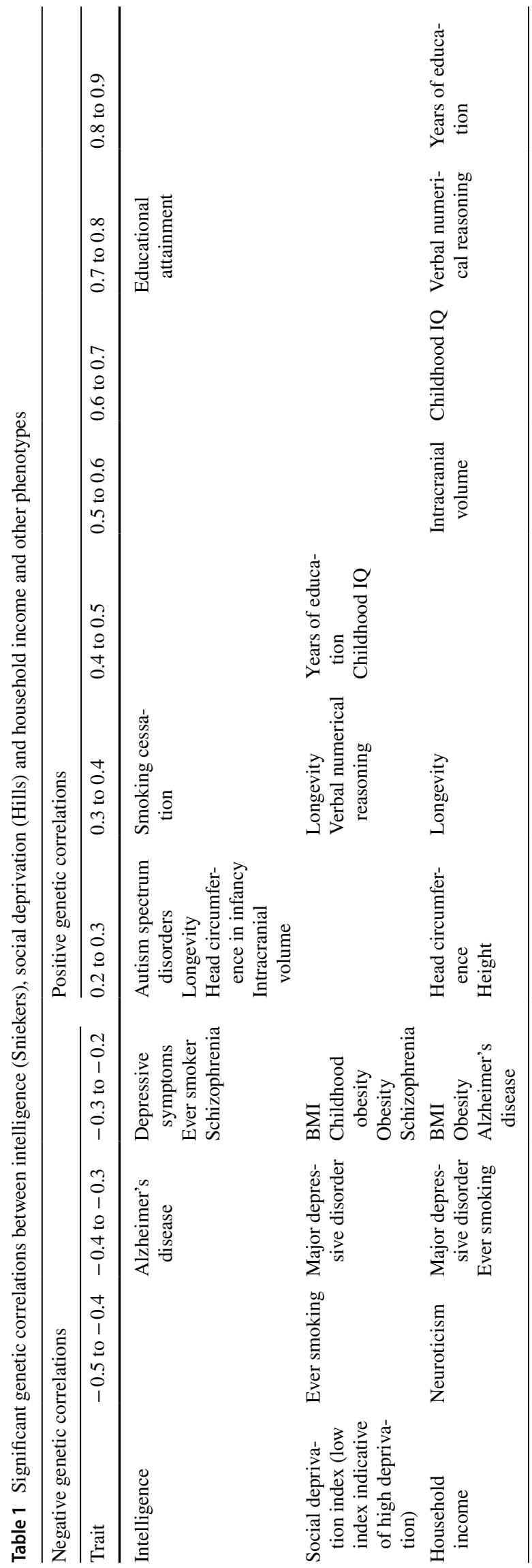

should be generalized with caution. In particular, individuals with higher educational attainment may have more training on tests of cognitive abilities, which could strengthen correlations between these two constructs. Second, data examining social deprivation in studies reporting genetic influences are based on aggregate neighborhood-rather than individual data [23]. Neighborhood-level socioeconomic factors cannot be considered adequate proxies of individual situations, and are more likely to suffer from misclassification bias (up to $30 \%$; [32]). In other words, it is difficult to say what type of life experience this measure actually captures. Third, much of the discussion regarding the relevance of genes in shaping intelligence and socioeconomic attainment leaves aside the role of environmental factors which obviously play an important role [33]. This argument is strengthened by the observation that IQ and educational levels have increased over time [34]: on average, in industrialized countries, IQ scores have risen by 0.2 SD per decade since 1950 [35]; during the same period, the percentage of 25-34 year olds with tertiary education across the OECD has increased from approximately 10 to $40 \%$ [36]. This "Flynn effect", which appears to have stalled in most countries more recently, cannot be explained by changes in the genetic composition of populations. Rather, it reflects environmental changes in demographic and socioeconomic patterns, nutrition, as well as educational and social (i.e., the number of children per family, average family income, access to higher education) policies. Similar phenomena have happened in other areas, for instance with regard to secular changes in body mass index and obesity rates. Despite the substantial increments in the rates of obesity over time, the heritability estimates for BMI have remained rather constant over the same time period [37]; we are unaware of a similar study for the assessment of heritability estimates for IQ. The BMI data clearly indicate that despite substantially increased rates of obesity, which highly likely reflect an environmental influence, both the fractions of the BMI variance attributable to genetic and environmental factors have not changed. Fourth, it has been shown that genetic influences on intelligence interact with socioeconomic factors and that the strength of the respective gene $x$ environment interactions varies across countries, highlighting the role of societal context and policy [38]. The idea that genetic factors alone will serve to reliably identify individuals who are likely to have high or low intelligence levels is simplistic.

Nevertheless, the detection of multiple loci proves that genetic factors that affect cognitive functioning exist and that - directly or indirectly - they have an impact on educational attainment and socioeconomic standing. Furthermore, if some of the above-cited methodological problems can be overcome, the power to detect more loci may well increase. For example, the use of a truly representative dataset could increase variability of both IQ and socioeconomic position 
and thus entail a higher probability of detecting genetic factors. Similarly, the use of individualized instead of neighborhood data could also boost power.

What are the implications of these research findings for child and adolescent psychiatry? What do we need to know, what issues need to be discussed critically? How will our societies use this novel information and how can we ensure that the results will not be abused? This editorial can open but a first door into this highly relevant discussion by making childhood mental health care professionals more aware of these recent developments. It should be pointed out that other fields in medicine are also confronted with the implications of the recent advances into the genetic architecture of complex diseases. It is conceivable that medicine in the future will rely on DNA arrays and algorithms to calculate individual polygenic risk scores for many diseases. The array in itself is inexpensive (its current cost is less than 100 Euros) particularly considering that the biometric analysis of SNP data will provide results applicable to the whole life span of the individual which may serve as a basis for individualized and cost-efficient preventive and diagnostic assessments. In addition, the increment in the understanding of the complex etiology of such diseases may drive the development of novel therapeutic interventions.

Obviously, polygenic risk scores will have no or little implications if they are in the medium or low range for a specific disorder. If, however, a high risk (e.g., individuals with polygenic risk scores in the top 1-5\%) ensues for a particular disease, prevention and early detection become important. Any given individual would thus likely have a high risk for single disorders only; the information content would clearly exceed that obtained via taking a complete family history. Such information would definitely impact our lives and societies as a whole; accordingly, the question arises whether we are willing and able to cope with such high risks for diseases, the onset of which may be decades away. Furthermore, how is this information going to be used in our societies (e.g., prenatal screening, screening to access certain schools or particular jobs)?

Without doubt, the elucidation of genes involved in intelligence and socioeconomic factors represents one of the most challenging societal issues within this context. In the following paragraph, we discuss a few issues that have come to the mind of the two authors.

1. Will IQ tests become obsolete? Will the assessment of a child's cognitive functioning in the future be based on blood sampling allowing the quantitative and qualitative identification of DNA variants involved in intelligence via a specific algorithm, rather than psychological diagnostics? The answer is a clear cut no. Environmental influence can definitely override the genetic makeup of an individual. This is definitely the case if severe envi- ronmental factors such as peri- and postpartal hypoxia or pre- and postnatal infections, as well as social deprivation impact the development of a child. To illustrate, a twin study [39] has shown that heritability estimates for IQ are high $(>0.8)$ in offspring raised by parents with high socioeconomic position. However, among children growing up in families with very low socioeconomic background, heritability estimates are close to zero. Similarly, a recent meta-analysis shows that interactions between genetic and socioeconomic factors with regard to children's intelligence and academic attainment are stronger in the United States than in Western Europe and Australia, suggesting that social and educational policies influence the predictive power of genetic factors [38].

2. Can these findings impact the diagnostic assessment of an individual child? A recent study exemplarily illustrates the potential of these novel findings for the assessment of reading performance in childhood. Thus, Plomin and coworkers [40] created individual-specific genetic scores (genome-wide polygenic scores; GPS) for years of education (based on [22]) to predict reading performance at ages 7,12 and 14 and on reading tests administered at ages 7 and 12 in an UK sample encompassing 5825 genotyped subjects representative of British families for ethnicity, family SES and parental occupation. The GPS accounted for up to 5\% of the variance in reading performance at age 14 . GPS predictions remained significant after accounting for general cognitive ability and family socioeconomic status. Reading performance of children in the lowest and highest octile $(12.5 \%)$ of the GPS distribution for educational attainment revealed differences of approximately $0.5,0.6$ and 0.7 of a standard deviation in their reading performance at ages 7,12 , and 14 , respectively. Because a difference of 0.60 of a standard deviation at age 12 corresponds to the mean growth of reading ability between grades 5 and 7 , the reading performance of children in the lowest GPS octile lagged two entire school years behind the reading performance of children within the highest GPS octile. The authors conclude "it seems certain that polygenic scores will be used to predict strengths and weaknesses in education" [40]. However, if this statement should imply a clinical or educational application, this conclusion must be challenged, because it potentially confounds the individual and population levels. A genetic test may be predictive in statistical terms, but a solid reading test will undoubtedly provide more information at the level of an individual child, assuming that he/she is motivated to participate in the reading test. In case a child is not motivated to have his/her reading performance assessed, a genetic test could be informative except that it would appear problematic and potentially unethical to perform it. In conclusion, it is hard to con- 
ceive of a benefit of genetic testing which would exceed the information gained via a child's performance on a reading test.

3. Can genetic information be used for screening purposes? Considering again the aforementioned example, it might be argued that a genetic test would allow a better prediction of future reading performance, particularly in a young child just starting to learn how to read or who is experiencing difficulties in his/her early reading career. This opens the door to early screening to detect children who have a high probability of reading difficulties. Undoubtedly, a genetically based screening could identify children at risk of high or low performance at a comparatively low cost; as a consequence, we can envision the use of specific training programs or even the placement of children in specific schools based on this information. Crucially, however, as for any other screening test, the benefits and risks of such an approach have to be assessed carefully (see Table 2; [41]). Such an endeavor could prove useful if specific interventions are available for those with a high-genetic risk of low performance; however, currently this is clearly not the case. Furthermore, and adding to concerns related to the introduction of screening of poor reading or math performance, many societies already have serious difficulties in providing sufficient support to children showing poor performance. For example, such children are frequently taught in schools located in low socioeconomic status neighborhoods. On average, these same schools have fewer available resources per individual child, thus curtailing their educational opportunities. The introduction of genetic tests to predict future academic performance clearly requires a societal consensus. Finally, and overall, the benefits of such screening would clearly have to outweigh its potential disadvantages, among which stigmatization ranks prominently. As such, we are extremely

Table 2 Assessment criteria for screening in the genomic age (Andermann et al. [41])

1. Recognized need

2. Objectives defined at the outset

3. Defined target population

4. Scientific evidence of effectiveness

5. Integration of education, testing, clinical services and program management

6. Quality assurance, with mechanisms to minimize potential risks of screening

7. Ensure informed choice, confidentiality and respect for autonomy

8. Promote equity and access to screening for the entire target population

9. Evaluation should be planned from the outset

10. Overall benefits of screening should outweigh the harm critical of directly or indirectly propagating the use of such genetic tests if knowledge required for the identification of beneficial and detrimental intended and unintended consequences is side stepped. We perceive the danger that genetic data can be used to further reduce the opportunities of children of low socioeconomic status because investments may further be focused only on children with the potential for high performance as based on a particular genetic risk score threshold. The combination of a biologically driven approach to academic performance with (a) educational systems that already favor pupils of higher socioeconomic standing and (b) political environments producing socioeconomic marginalization is not a recipe for the future.

4. Will genetic information benefit research? This answer to this question is a clear-cut yes. We are for the first time able to assess factors that impact intelligence and that explain a sizeable proportion of population variance in IQ. Based on the aforementioned example of reading performance, we envision substantial progress for the genetic dissection of dyslexia and dyscalculia. Genetic correlations between these two phenotypes and intelligence can be calculated based on existing datasets. In upcoming years, the specific functions of the polygenes involved in intelligence are likely to be better understood. In addition, we will get a grasp of the main mechanisms involved-data that already exist point to the importance of myelinisation and neurogenesis [20]. Importantly, we will also be able to comprehend what phenotypes and what childhood mental disorders are genetically correlated with intelligence. This appears an extremely important albeit sensitive research area in light of the substantially increased risk of mental disorders in populations with low socioeconomic position.

To conclude, we perceive the urgent need for a thorough discussion of the implications of the ongoing molecular elucidation of mental phenotypes among childhood mental health professionals. This holds particularly true for intelligence and socioeconomic factors due to their strong influence on health in general and on mental health in particular. We currently do not see a role for the determination of genetic risk scores for low IQ or related phenotypes, because this information does not add to that obtained via classic psychological assessment tools. We caution against the uncritical direct or indirect propagation of genetic tests because these make sense in the context of populationrather than individual-screening only. As with any other screening test, particular care is required to ensure that the benefits outweigh the disadvantages. We encourage mental health care professionals to carefully distinguish between the individual and population levels. We need to become more knowledgeable of these exciting novel findings to ensure that 
we can make the best use of them for our individual patients and to circumvent an uncritical and hasty "biologicalization" of these results within the broader societal context-particularly in societies, in which individual strengths are deemed relevant. We realize that a thorough understanding of these issues requires child mental health care professionals who are willing to perform research focusing on the molecular elucidation of complex phenotypes and interpret the findings in light of their clinical relevance. Accordingly, we must involve our young researchers in this rapidly evolving field.

Acknowledgements The authors thank Anke Hinney, Jochen Antel and Lars Libuda (Essen) for their critical comments.

\section{References}

1. Guedeney A, Doukhan S, Forhan A, Heude B, Peyre H, EDEN Mother-Child Cohort Study Group (2017) To which extent social withdrawal at the age of 1 year is associated with IQ at 5-6 years old? Results of the EDEN mother-child cohort. Eur Child Adolesc Psychiatry 26(11):1343-1350. https://doi.org/10.1007/s0078 7-017-0988-9 (Epub 2017 Apr 17)

2. Lin SK, Tsai CH, Li HJ, Huang CY, Chen KL (2017) Theory of mind predominantly associated with the quality, not quantity, of pretend play in children with autism spectrum disorder. Eur Child Adolesc Psychiatry 26(10):1187-1196. https://doi.org/10.1007/ s00787-017-0973-3 (Epub 2017 Mar 16)

3. Liu J, Yao L, Zhang W, Xiao Y, Liu L, Gao X, Shah C, Li S, Tao B, Gong Q, Lui S (2017) Gray matter abnormalities in pediatric autism spectrum disorder: a meta-analysis with signed differential mapping. Eur Child Adolesc Psychiatry 26(8):933-945. https:// doi.org/10.1007/s00787-017-0964-4 (Epub 2017 Feb 23)

4. Ma I, Lambregts-Rommelse NN, Buitelaar JK, Cillessen AH, Scheres AP (2017) Decision-making in social contexts in youth with ADHD. Eur Child Adolesc Psychiatry 26(3):335-344

5. Martínez K, Merchán-Naranjo J, Pina-Camacho L, AlemánGómez Y, Boada L, Fraguas D, Moreno C, Arango C, Janssen J, Parellada M (2017) Atypical age-dependency of executive function and white matter microstructure in children and adolescents with autism spectrum disorders. Eur Child Adolesc Psychiatry 26(11):1361-1376. https://doi.org/10.1007/s00787-017-0990-2 (Epub 2017 Apr 26)

6. Morsink S, Sonuga-Barke E, Mies G, Glorie N, Lemiere J, Van der Oord S, Danckaerts M (2017) What motivates individuals with ADHD? A qualitative analysis from the adolescent's point of view. Eur Child Adolesc Psychiatry 26(8):923-932. https://doi. org/10.1007/s00787-017-0961-7 (Epub 2017 Feb 23)

7. Mottron L (2017) Should we change targets and methods of early intervention in autism, in favor of a strengths-based education? Eur Child Adolesc Psychiatry 26(7):815-825. https://doi. org/10.1007/s00787-017-0955-5 (Epub 2017 Feb 8)

8. Mous SE, Overwater IE, Vidal Gato R, Duvekot J, Ten Hoopen LW, Lequin MH, de Wit MY, Dieleman GC (2017) Cortical dysplasia and autistic trait severity in children with Tuberous Sclerosis Complex: a clinical epidemiological study. Eur Child Adolesc Psychiatry. https://doi.org/10.1007/s00787-017-1066-z (Epub ahead of print)

9. Petruzzelli MG, Margari L, Bosco A, Craig F, Palumbi R, Margari F (2017) Early onset first episode psychosis: dimensional structure of symptoms, clinical subtypes and related neurodevelopmental markers. Eur Child Adolesc Psychiatry. https://doi.org/10.1007/ s00787-017-1026-7 (Epub ahead of print)

10. Tor J, Dolz M, Sintes A, Muñoz D, Pardo M, de la Serna E, Puig O, Sugranyes G, Baeza I (2017) Clinical high risk for psychosis in children and adolescents: a systematic review. Eur Child Adolesc Psychiatry. https://doi.org/10.1007/s00787-017-1046-3 (Epub ahead of print) (Review)

11. Binet A, Simon T (1905) Méthodes nouvelles pour le diagnostic du niveau intellectuel des anormaux. L'Année psychologique $11: 191-244$

12. Boake C (2002) From the Binet-Simon to the Wechsler-Bellevue: tracing the history of intelligence testing. J Clin Exp Neuropsychol 24(3):383-405

13. Jensen AR (1998) Human evolution, behavior, and intelligence. The $g$ factor: the science of mental ability. Praeger Publishers/ Greenwood Publishing Group, Westport

14. Galton F (1892) Hereditary genius: an inquiry into its laws and consequences. Watts \& Co, London

15. Bouchard TJ, McGue M (2003) Genetic and environmental influences on human psychological differences. Dev Neurobiol 54(1):4-45

16. Krapohl E, Rimfeld K, Shakeshaft NG, Trzaskowski M, McMillan A, Pingault JB, Asbury K, Harlaar N, Kovas Y, Dale PS, Plomin R (2014) The high heritability of educational achievement reflects many genetically influenced traits, not just intelligence. Proc Natl Acad Sci USA 111(42):15273-15278. https://doi.org/10.1073/ pnas. 1408777111

17. Sariaslan A, Fazel S, D’Onofrio BM, Långström N, Larsson H, Bergen SE, Kuja-Halkola R, Lichtenstein P (2016) Schizophrenia and subsequent neighborhood deprivation: revisiting the social drift hypothesis using population, twin and molecular genetic data. Trans1 Psychiatry 3(6):e796. https://doi.org/10.1038/ tp.2016.62

18. Davies G, Marioni RE, Liewald DC, Hill WD, Hagenaars SP, Harris SE, Ritchie SJ, Luciano M, Fawns-Ritchie C, Lyall D, Cullen B, Cox SR, Hayward C, Porteous DJ, Evans J, McIntosh AM, Gallacher J, Craddock N, Pell JP, Smith DJ, Gale CR, Deary IJ (2016) Genome-wide association study of cognitive functions and educational attainment in UK Biobank $(N=112151)$. Mol Psychiatry 21(6):758-767

19. Sniekers S, Stringer S, Watanabe K, Jansen PR, Coleman JRI, Krapohl E, Taskesen E, Hammerschlag AR, Okbay A, Zabaneh D, Amin N, Breen G, Cesarini D, Chabris CF, Iacono WG, Ikram MA, Johannesson M, Koellinger P, Lee JJ, Magnusson PKE, McGue M, Miller MB, Ollier WER, Payton A, Pendleton N, Plomin R, Rietveld CA, Tiemeier H, van Duijn CM, Posthuma D (2017) Genome-wide association meta-analysis of 78,308 individuals identifies new loci and genes influencing human intelligence. Nat Genet 49(7):1107-1112

20. Hill WD, Marioni RE, Maghzian O, Ritchie SJ, Hagenaars SP, McIntosh AM, Gale CR, Davies G, Deary IJ (2018) A combined analysis of genetically correlated traits identifies 187 loci and a role for neurogenesis and myelination in intelligence. Mol Psychiatry. https://doi.org/10.1038/s41380-017-0001-5

21. Okbay A, Beauchamp JP, Fontana MA, Lee JJ, Pers TH, Rietveld CA, Turley P, Chen GB, Emilsson V, Meddens SF, Oskarsson S, Pickrell JK, Thom K, Timshel P, de Vlaming R, Abdellaoui A, Ahluwalia TS, Bacelis J, Baumbach C, Bjornsdottir G, Brandsma JH, Pina Concas M, Derringer J, Furlotte NA, Galesloot TE, Girotto G, Gupta R, Hall LM, Harris SE, Hofer E, Horikoshi M, Huffman JE, Kaasik K, Kalafati IP, Karlsson R, Kong A, Lahti J, van der Lee SJ, deLeeuw C, Lind PA, Lindgren KO, Liu T, Mangino M, Marten J, Mihailov E, Miller MB, van der Most PJ, Oldmeadow C, Payton A, Pervjakova N, Peyrot WJ, Qian Y, Raitakari O, Rueedi R, Salvi E, Schmidt B, Schraut KE, Shi J, Smith AV, Poot RA, St Pourcain B, Teumer A, Thorleifsson G, 
Verweij N, Vuckovic D, Wellmann J, Westra HJ, Yang J, Zhao W, Zhu Z, Alizadeh BZ, Amin N, Bakshi A, Baumeister SE, Biino G, Bønnelykke K, Boyle PA, Campbell H, Cappuccio FP, Davies G, De Neve JE, Deloukas P, Demuth I, Ding J, Eibich P, Eisele L, Eklund N, Evans DM, Faul JD, Feitosa MF, Forstner AJ, Gandin I, Gunnarsson B, Halldórsson BV, Harris TB, Heath AC, Hocking LJ, Holliday EG, Homuth G, Horan MA, Hottenga JJ, de Jager PL, Joshi PK, Jugessur A, Kaakinen MA, Kähönen M, Kanoni S, Keltigangas-Järvinen L, Kiemeney LA, Kolcic I, Koskinen S, Kraja AT, Kroh M, Kutalik Z, Latvala A, Launer LJ, Lebreton MP, Levinson DF, Lichtenstein P, Lichtner P, Liewald DC, LifeLines Cohort Study, Loukola A, Madden PA, Mägi R, Mäki-Opas T, Marioni RE, Marques-Vidal P, Meddens GA, McMahon G, Meisinger C, Meitinger T, Milaneschi Y, Milani L, Montgomery GW, Myhre R, Nelson CP, Nyholt DR, Ollier WE, Palotie A, Paternoster L, Pedersen NL, Petrovic KE, Porteous DJ, Räikkönen K, Ring SM, Robino A, Rostapshova O, Rudan I, Rustichini A, Salomaa V, Sanders AR, Sarin AP, Schmidt H, Scott RJ, Smith BH, Smith JA, Staessen JA, Steinhagen-Thiessen E, Strauch K, Terracciano A, Tobin MD, Ulivi S, Vaccargiu S, Quaye L, van Rooij FJ, Venturini C, Vinkhuyzen AA, Völker U, Völzke H, Vonk JM, Vozzi D, Waage J, Ware EB, Willemsen G, Attia JR, Bennett DA, Berger K, Bertram L, Bisgaard H, Boomsma DI, Borecki IB, Bültmann U, Chabris CF, Cucca F, Cusi D, Deary IJ, Dedoussis GV, van Duijn CM, Eriksson JG, Franke B, Franke L, Gasparini P, Gejman PV, Gieger C, Grabe HJ, Gratten J, Groenen PJ, Gudnason V, van der Harst P, Hayward C, Hinds DA, Hoffmann W, Hyppönen E, Iacono WG, Jacobsson B, Järvelin MR, Jöckel KH, Kaprio J, Kardia SL, Lehtimäki T, Lehrer SF, Magnusson PK, Martin NG, McGue M, Metspalu A, Pendleton N, Penninx BW, Perola M, Pirastu N, Pirastu M, Polasek O, Posthuma D, Power C, Province MA, Samani NJ, Schlessinger D, Schmidt R, Sørensen TI, Spector TD, Stefansson K, Thorsteinsdottir U, Thurik AR, Timpson NJ, Tiemeier H, Tung JY, Uitterlinden AG, Vitart V, Vollenweider P, Weir DR, Wilson JF, Wright AF, Conley DC, Krueger RF, Davey Smith G, Hofman A, Laibson DI, Medland SE, Meyer MN, Yang J, Johannesson M, Visscher PM, Esko T, Koellinger PD, Cesarini D, Benjamin DJ (2016) Genome-wide association study identifies 74 loci associated with educational attainment. Nature 533(7604):539-542

22. Selzam S, Krapohl E, von Stumm S, O'Reilly PF, Rimfeld K, Kovas Y, Dale PS, Lee JJ, Plomin R (2017) Predicting educational achievement from DNA. Mol Psychiatry 22(2):267-272. https://doi.org/10.1038/mp.2016.107 (Epub 2016 Jul 19) [Erratum in: Mol Psychiatry (2017)]

23. Hill WD, Hagenaars SP, Marioni RE, Harris SE, Liewald DCM, Davies G, Okbay A, McIntosh AM, Gale CR, Deary IJ (2016) Molecular genetic contributions to social deprivation and household income in UK Biobank. Curr Biol 26(22):3083-3089

24. Akiyama M, Okada Y, Kanai M, Takahashi A, Momozawa Y, Ikeda M, Iwata N, Ikegawa S, Hirata M, Matsuda K, Iwasaki M, Yamaji T, Sawada N, Hachiya T, Tanno K, Shimizu A, Hozawa A, Minegishi N, Tsugane S, Yamamoto M, Kubo M, Kamatani Y (2017) Genome-wide association study identifies 112 new loci for body mass index in the Japanese population. Nat Genet 49(10):1458-1467

25. Manolio TA, Collins FS, Cox NJ, Goldstein DB, Hindorff LA, Hunter DJ, McCarthy MI, Ramos EM, Cardon LR, Chakravarti A, Cho JH, Guttmacher AE, Kong A, Kruglyak L, Mardis E, Rotimi CN, Slatkin M, Valle D, Whittemore AS, Boehnke M, Clark AG, Eichler EE, Gibson G, Haines JL, Mackay TF, McCarroll SA, Visscher PM (2009) Finding the missing heritability of complex diseases. Nature 461(7265):747-753

26. Gibson G (2010) Hints of hidden heritability in GWAS. Nat Genet 42(7):558-560
27. Sauce B, Matzel LD (2018) The paradox of intelligence: heritability and malleability coexist in hidden gene-environment interplay. Psychol Bull 144(1):26-47. https://doi.org/10.1037/bul0000131 (Epub 2017 Oct 30)

28. Bulik-Sullivan B, Finucane HK, Anttila V, Gusev A, Day FR, Loh PR, ReproGen Consortium, Psychiatric Genomics Consortium, Genetic Consortium for Anorexia Nervosa of the Wellcome Trust Case Control Consortium 3, Duncan L, Perry JR, Patterson N, Robinson EB, Daly MJ, Price AL, Neale BM (2015) An atlas of genetic correlations across human diseases and traits. Nat Genet 47(11):1236-1241

29. Rousseau J-J (2016) Discours sur l'origine et les fondements de l'inégalité parmi les hommes. GF Flammarion, Paris

30. Nisbett RE, Aronson J, Blair C, Dickens W, Flynn J, Halpern DF, Turkheimer E (2012) Intelligence: new findings and theoretical developments. Am Psychol 67(2):130-159. https://doi. org/10.1037/a0026699 (Epub 2012 Jan 2) (Review)

31. Bergman-Nutley S, Klingberg T (2014) Effect of working memory training on working memory, arithmetic and following instructions. Psychol Res 78(6):869-877. https://doi.org/10.1007/s0042 6-014-0614-0 (Epub 2014 Sep 27)

32. Day SE, Hinterland K, Myers C, Gupta L, Harris TG, Konty KJ (2016) A school-level proxy measure for individual-level poverty using school-level eligibility for free and reduced-price meals. J Sch Health 86(3):204-214. https://doi.org/10.1111/josh.12371

33. Plomin R, Daniels D (2011) Why are children in the same family so different from one another? Int J Epidemiol 40(3):563-582. https://doi.org/10.1093/ije/dyq148 (Review)

34. Jokela M, Pekkarinen T, Sarvimäki M, Terviö M, Uusitalo R (2017) Secular rise in economically valuable personality traits. Proc Natl Acad Sci USA 114(25):6527-6532

35. Pietschnig J, Penke L, Wicherts JM, Zeiler M, Voracek M (2015) Meta-analysis of associations between human brain volume and intelligence differences: how strong are they and what do they mean? Neurosci Biobehav Rev 57:411-432. https://doi. org/10.1016/j.neubiorev.2015.09.017

36. OECD (2017) Education at a glance. https://static.rasset.ie/docum ents/news/2017/09/oecd.pdf

37. Silventoinen K, Jelenkovic A, Sund R, Yokoyama Y, Hur YM, Cozen W, Hwang AE, Mack TM, Honda C, Inui F, Iwatani Y, Watanabe M, Tomizawa R, Pietiläinen KH, Rissanen A, Siribaddana SH, Hotopf M, Sumathipala A, Rijsdijk F, Tan Q, Zhang D, Pang Z, Piirtola M, Aaltonen S, Öncel SY, Aliev F, Rebato E, Hjelmborg JB, Christensen K, Skytthe A, Kyvik KO, Silberg JL, Eaves LJ, Cutler TL, Ordoñana JR, Sánchez-Romera JF, ColodroConde L, Song YM, Yang S, Lee K, Franz CE, Kremen WS, Lyons MJ, Busjahn A, Nelson TL, Whitfield KE, Kandler C, Jang KL, Gatz M, Butler DA, Stazi MA, Fagnani C, D'Ippolito C, Duncan GE, Buchwald D, Martin NG, Medland SE, Montgomery GW, Jeong HU, Swan GE, Krasnow R, Magnusson PK, Pedersen NL, Dahl Aslan AK, McAdams TA, Eley TC, Gregory AM, Tynelius P, Baker LA, Tuvblad C, Bayasgalan G, Narandalai D, Spector TD, Mangino M, Lachance G, Burt SA, Klump KL, Harris JR, Brandt I, Nilsen TS, Krueger RF, McGue M, Pahlen S, Corley RP, Huibregtse BM, Bartels M, van Beijsterveldt CE, Willemsen G, Goldberg JH, Rasmussen F, Tarnoki AD, Tarnoki DL, Derom CA, Vlietinck RF, Loos RJ, Hopper JL, Sung J, Maes HH, Turkheimer E, Boomsma DI, Sørensen TI, Kaprio J (2017) Differences in genetic and environmental variation in adult BMI by sex, age, time period, and region: an individual-based pooled analysis of 40 twin cohorts. Am J Clin Nutr 106(2):457-466

38. Tucker-Drob EM, Bates TC (2016) Large cross-national differences in gene $\times$ socioeconomic status interaction on intelligence. Psychol Sci 27(2):138-149 
39. Turkheimer E, Haley A, Waldron M, D'Onofrio B, Gottesman II (2003) Socioeconomic status modifies heritability of IQ in young children. Psychol Sci 14(6):623-628

40. Selzam S, Dale PS, Wagner RK, DeFries JC, Cederlöf M, O'Reilly PF, Krapohl E, Plomin R (2017) Genome-wide polygenic scores predict reading performance throughout the school years.
Sci Stud Read 21(4):334-349. https://doi.org/10.1080/10888 438.2017.1299152

41. Andermann A, Blancquaert I, Beauchamp S, Déry V (2008) Revisiting Wilson and Jungner in the genomic age: a review of screening criteria over the past 40 years. Bull World Health Organ 86(4):317-319 